Vol. 5, No. 2, 2020

\title{
THE LIFE PATH AND SCIENTIFIC ACTIVITY OF PROFESSOR DARIUSZ KOWALSKI
}

\author{
Beata Kowalska \\ Department of Water Supply and Wastewater Disposal, \\ Faculty of Environmental Engineering, \\ Lublin University of Technology, \\ 40B Nadbystrzycka Str., Lublin, 20-618, Poland \\ b.kowalska@pollub.pl
}

https://doi.org/10.23939/ep2020.02.065

Received: 12.02 .2020

(C) Kowalska B., 2020

\begin{abstract}
The article describes the stages of professional formation and scientific priorities of Professor Dariusz Kowalski completed schools, acquired degrees and professional experience, as well as a list of the most important publications. The following is a description of the main scientific research results and possibilities for their practical application.
\end{abstract}

Key words: scientific research, water supply, secondary contamination, counteraction.

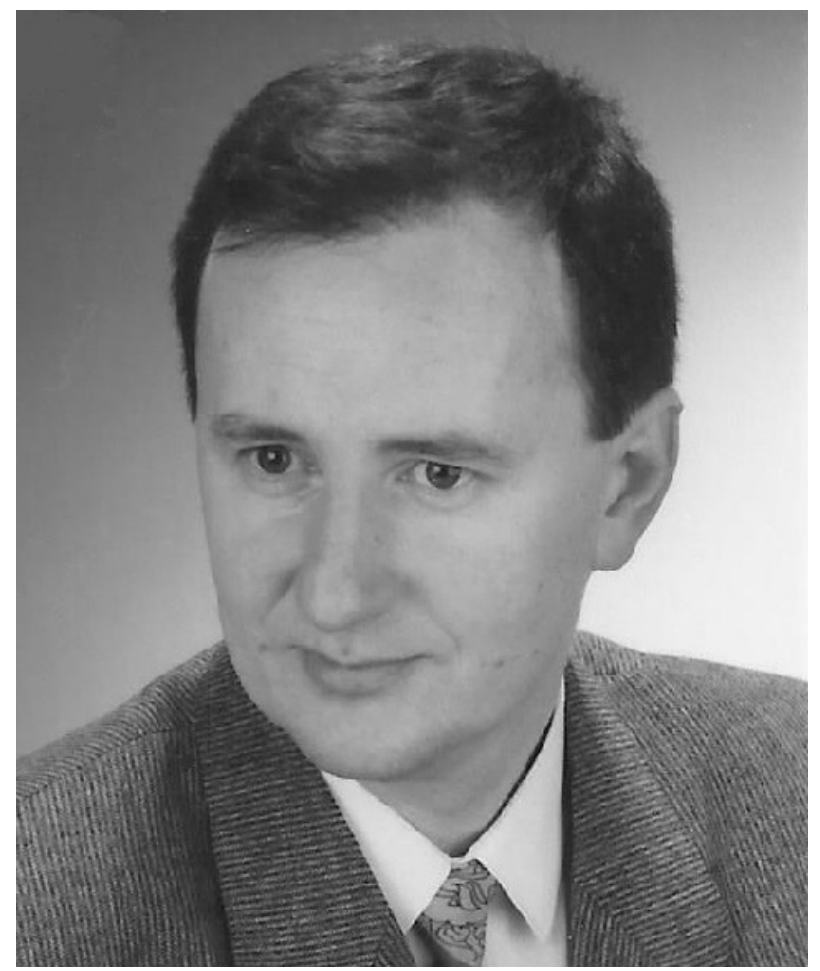

Dariusz Kowalski, habilitated doctor of technical sciences, professor of Lublin University of Technology
(Poland), member of Department of Water Supply and Wastewater Disposal in Faculty of Environmental Engineering at Lublin University of Technology.

Dariusz Kowalski was born in 1962 in Lublin, and his life and career path is connected with this city. $\mathrm{He}$ began his education at the State Primary and Secondary Music School, which he graduated with distinction, obtaining the title of a professional musician. To the surprise of his teachers and family, after graduation he decided to change the direction of education - he passed the entrance exams and started studying in the Faculty of Civil and Sanitary Engineering (scientific discipline: Environmental Engineering, specialty: thermal and sanitary equipment) at the Lublin University of Technology. He graduated in 1986 with a very good result. A year earlier, still as a student, he was employed in the Department of Heating and Water Supply of this faculty. In 1986, he also completed post-graduate pedagogical programme for university teaching staff at the Maria Curie-Skłodowska University in Lublin. From 1994 on, he worked in the Department of Water Supply and Sewage Disposal. After organizational changes at the Lublin University of Technology in 2005, he started to work at the Faculty of Environmental Engineering, where he works until today in the Department of Water Supply and Sewage Disposal. During his work at the university, he went through all career levels: intern, junior and senior assistant, assistant professor and university professor.

In addition to his scientific achievements, Dariusz Kowalski also gained practical knowledge. For 10 years, he cooperated with "Budoexpert" design group at the Lublin University of Technology. For two years, he worked as an assistant designer at ROLWIK design 
company and later on in the Provincial Board of Land Reclamation in Lublin. The design experience he gained while working at school and hospital construction sites as a manager of sanitary works, was successfully implemented by Military Construction Works in Jarosław and REMKON company in Lublin. What is more, in 1999 he completed an internship at a design office in Deventer (The Netherlands) where he worked on the design of a flood control system.

In 2005, for his practical experience and positive result of the exam taken before the Lublin Group of Civil Engineers, he was granted rights to design and manage construction projects in the field of networks, installations and sanitary equipment.

In the beginnings of his work at the university supervised Kazimierz Bonetyński PhD Eng., he dealt with issues related to water supply and sewage systems, with particular emphasis on their design and operation. In 1994, professor Wenanty Olszta became the new head of the Department of Water Supply and Wastewater Removal. This meant that scientific interests of Dariusz Kowalski had to evolve towards water management in the Soil-Plant-Atmosphere system. His knowledge of the basics of soil physics and methods of numerical modeling of water and nitrogen transport in this system allowed him to join an intercollegiate team implementing the "Development of an integrated urban wastewater treatment system connected with irrigation of industrial crops" project financed by the Ministry of Science and Higher Education (No. PBZ-31-03). In the scope of this project, Dariusz Kowalski studied changes in water conductivity and retention capacity of organic soils heavily fertilized with municipal wastewater. He also built a numerical model for the growth of plants inhabiting these soils, which allowed to determine optimum irrigation doses in varying weather conditions [1]. Scientific experience gained in this project and cooperation with the Institutes of the Polish Academy of Sciences: Agrophysics (Lublin), Land Reclamation (Lublin) and Water Construction (Gdańsk) resulted in the dissertation entitled "Assessment of the possibility of reclamation of land degraded by groundwater intake, on the example of the Stawek-Stoki Valley", supervised by professor Wenanty Olszta. This dissertation allowed him to obtain a PhD degree in 1996 at the Faculty of Land Reclamation and Environmental Engineering of Warsaw University of Life Sciences.

After being conferred a doctoral degree, Dariusz Kowalski began working on an innovative anti-erosion protection system for areas covered by loess deposits, invented by Jan Rubaj, MSc. This system was based on the construction of damming barriers, equipped with ditches and infiltration wells, located on hill slopes and valleys. Implementation of this system also limited pollution in the area associated with runoff of fertilizer and plant protection products to rivers. The research on this system was to determine the effectiveness of the above structures and to develop a method designing and locating them in the field [2-6]. This task was carried out as part of the research project 1564 / T09 / 2001/21 completed in 2004 named "Pilot Program of Antierosion Protection" financed by the Polish Scientific Research Committee. The implemented protection system was presented and acknowledged in 2002 at the "Environmentally Friendly" exhibition organized by the Senate of the Polish Parliament.

Another change in the structure of the Lublin University of Technology, i.e. establishment of the Faculty of Environmental Engineering, led to modification of issues researched by Dariusz Kowalski. Within this Faculty, Water and Sewage Department was established. Professor Marian Kwietniewski became the head of the department. Cooperation with professor Kwietniewski made it possible to return to the issues related to design and operation of water supply systems, with particular emphasis on secondary water pollution in these systems. The researched issues resulted in granting and implementation three research projects financed by the Ministry of Science and Higher Education:

- 4 T09D 04624, "Formation and spread of pollution in an oversized water supply network", completed in 2006, supervised by Dariusz Kowalski,

- 4942 / B / T02 / 2008/34, "Methodology of water quality and pressure management in water supply networks", completed in 2011, supervised by professor Marian Kwietniewski,

- 4508 / B / T02 / 2009/36, "The influence of material on the quality of tap water in pipelines made of plastics", completed in 2011, supervised by professor Beata Kowalska.

Recognition of activities carried out as part of the above projects by the Polish scientific community resulted in the invitation of Dariusz Kowalski to participate in the inter-university research project 1056/R/T02/2010/10 named "Development of a comprehensive method for assessing the reliability and security of water supply to consumers", completed in 2013, supervised by professor Janusz Rak from the Rzeszów University of Technology.

Research carried out under all of the above projects was aimed at improving the security of a water supply through distribution systems. After political transformations started in 1989, Poland has observed a very significant decrease in water consumption. The average daily water consumption per person rapidly fell down from approx. 250 to $100 \mathrm{dm}^{3}$. Consumption of water by industrial customers also dropped significantly. Consequently, the hydraulic working conditions in almost all water systems in Poland deteriorated. Water flow velocities in pipelines have dropped significantly in comparison to those planned. The so called water age in water supply systems has increased, in many cases 
reaching several weeks. The quality of water supplied to consumers began to deteriorate despite significant investments aimed at modernizing water treatment plants. Consequently, new research issues began to dominate the previously overlooked phenomenon of secondary water: secondary pollution in distribution systems and improving the security of a water supply. Dariusz Kowalski has actively joined this trend. He conducted his research in cooperation with other members of the Department and representatives of local water companies, mainly on existing networks. His main research issues included:

- identification of sources of secondary water pollution, with particular emphasis on the impact of conditions of hydraulic work and of pipe material on the quality of transmitted water [7-10],

- numerical modeling of water supply systems [11-13],

- design of distribution system monitoring system [14],

- developing methods to counteract the effects of secondary pollution [15-17],

- evaluation of water supply systems reliability [18-21].

While carrying out the above research tasks, Dariusz Kowalski noticed that one of the elements connecting the issues of hydraulics, secondary pollution and reliability of a water supply networks is the correct description of their geometric structures. The search for a universal method of this description led him to use elements of the theory of fractal geometry. Interestingly, during this research he has developed a mathematical formula allowing to describe almost any geometric structure of a water supply network. Using the theory of fractal geometry enabled him to develop several new methods related to classification, design and operation of water supply networks. Their main advantage is their universal character - they can be used for almost any type of a water supply system. These methods have been included in the monograph "New methods for describing water supply network structures to solve problems of their design and operation" [23]. This monograph has become the basis for applying for the habilitated doctor degree, ultimately obtained by him at the Faculty of Environmental Engineering of the Wrocław University of Technology.

After obtaining the degree of habilitated doctor in 2012, Dariusz Kowalski continued working on issues of improving the security of a water supply. He expanded his previous research tools to include GIS databases and numerical modeling of sewer systems [24]. This allowed him to actively participate in the project implemented by Water Company in Puławy - "Preparation of assumptions and implementation of an integrated technical infrastructure management system of the enterprise" [25]. The project was co-financed by the European Union. As part of this project, he developed methods for determining the location of pressure measurement points, flow rate and water quality. This allowed him to design the monitoring system of the water distribution system currently operating in this town. The observed negative effects of the water hammer phenomena on the work of the pumping station and the quality of the water pumped by them, resulted in the development of two solutions for counteracting devices. These solutions, implemented in the rural water supply system, formed the basis of the doctoral dissertation defended in 2018 by his student Artur Choma MSc., whom Dariusz Kowalski supervised.

Professor Kowalski is currently working on the following issues:

- a smart water supply and sewage network management system [26], where he created the main concept of the project and cooperated in the implementation of software integrating the GIS database, SCADA monitoring system and numerical model of a water supply network. This project is co-financed by the European Union. The expected project completion date is May 2020,

- construction of a prototype and implementation of production: a universal saddle for drilling pipelines and a new type of sewage manhole. Both projects are implemented as a part of the Innovation Incubator 2.0 program financed by the Ministry of Science and Higher Education. Completion date: April 2020.

Professor Kowalski actively cooperates with various foreign scientific centers. In cooperation with professor Mykola Hirol from the National University of Water and Environmental Engineering in Rivne (Ukraine), he has published a number of scientific papers, a monograph [27] and patented several technical solutions. Cooperation with the Lviv Polytechnic (Ukraine) and the Polish Academy of Sciences Scientific Center in Kiev resulted in a periodical conference "Water supply and wastewater removal: designing, construction, operation and monitoring" organized in Lviv since 2015. Thanks to cooperation with the Wessex Institute of Technology (UK), professor Kowalski became a member of the scientific committee of the cyclical URBAN WATER conference - later re-named as FRIAR.

What is more, professor Kowalski completed a number of short-term internships at the Center for Water Systems at the University of Exeter (UK) and in the Department of Technologies and Materials at the Technical University of Kosice (Slovakia).

A characteristic feature of research conducted by Dariusz Kowalski is the measurable practical aspect. Based on theoretical research, he developed numerous (25) technical solutions that were granted patent protection. Five of them were honored at the International Invention Exhibitions in Warsaw $(2016,2019)$ and in Valencia, Spain (2019). In 2018, he was awarded the Leader of Innovation title by the Polish magazine Leaders of Innovation. 
Professor Kowalski has published the results of his scientific research in almost 190 papers. He also presented them at the meetings of the Committee for Water and Civil Engineering and the Section of Sanitary Engineering in this Committee at the Polish Academy of Sciences. He also popularized his achievements during workshops conducted by the Association of Engineers and Technicians of the National Technical Organization in Poland. Together with a group of experts appointed by the Polish Water Chamber of Commerce, he developed guidelines for the design of water supply and sewage networks [28].

A significant part of professor Kowalski's work is teaching activity. In his professional career, he has lectured, conducted auditorium, design and laboratory exercises related to the subject of sanitary devices, with particular emphasis on water supply and sewage systems. He was a supervisor of over 250 bachelor's and master's theses, as well as of 1 doctoral dissertation. He was also requested to review 5 doctoral and 6 habilitation dissertations at various universities in Poland. For two years, he cooperated with the Polish Accreditation Committee of the Ministry of Higher Education and the Accreditation Committee of Technical Universities, as an expert appointed to evaluate the study programs of various universities in Poland.

Professor Kowalski is a member of the Association of Land Reclamation Engineers and Technicians, the National Technical Organization. For two terms, he sat on the board of the Lublin section of this association.

Privately, Dariusz Kowalski continues his lifelong interest in music. He has been continuously active as a baritone in the Lublin University of Technology Choir since 1981. For many years, he was the Choir's accompanist, tutor and soloist. Between 2015-2018, he also cooperated with "Lutnia" Lublin Philharmonic Choir.

\section{References}

[1] Kowalski D., Olszta W.: Model wzrostu roślin oraz transportu wody i zanieczyszczeń, w: III $^{\circ}$ Oczyszczania ścieków miejskich w agrosystemach [in:] Filipek T. (Ed.), Akademia Rolnicza Lublin 1998, 303-364.

[2] Kowalski D., Rubaj J., Widomski M.: Acta Agrophysica, 2005, 115, 57.

[3] Kowalski D., Rubaj J., Widomski M.: Acta Agrophysica, 2005, 116, 315.

[4] Olszta W., Kowalski D.: Acta Agrophysica, Rozprawy i Monografie, 2005, 121 (4).

[5] Widomski M., Kowalski D., Łagód G.: Modelowanie ruchu wody i transportu zanieczyszczeń w ośrodku porowatym. Przykłady zastosowania programu FEFLOW [in:] Pawłowski L. (Ed.), Podręczniki Inżynierii Środowiska, seria wydawnicza Komitetu Inżynierii Środowiska PAN 2013.

[6] Widomski M., Kowalski D., Iwanek M., Łagód G. Modeling of water flow and pollutants transport in porous media : with exemplary calculations in FEFLOW, Politechnika Lubelska 2013.

[7] Kowalska B., Kowalski D., Rożej A.: J. Water Supply Res. Technol. - AQUA, 2011, 60, 137.

[8] Kowalska B., Kowalski D., Suchorab P., Iwanek M.: Secondary water contamination in selected rural supply network [in:] Zimoch I.(Ed.), Current issues in water treatment and water distribution, Politechnika Śląska, Gliwice 2016, 161-172.

[9] Rożej A., Cydzik-Kwiatkowska A., Kowalska B., Kowalski D.: World J. Microbiol. \& Biotechnol., 2015, $31,37$.

[10] Wąsowski J., Kowalski D., Kowalska B. et al.: Applied Sci.-Basel, 2019, 9(7), 1348.

[11] Kowalska B., Musz A., Kowalski D.: Polish J. Environ. Studies, 2009, 18, 169.

[12] Hołota E., Kowalska B., Kowalski D.: Instal, 2018, 12, 55.

[13] Kowalski D., Kowalska B., Hirol M., Hoołota E.: Polska Inżynieria Środowiska: prace, 2012, 2, 235.

[14] Kowalski D., Kowalska B., Kwietniewski M.: Bull.of The Polish Academy Of Sci.-Tech. Sci., 2015, 63, 155.

[15] Kowalski D., Kowalska B., Hołota E., Choma A.: Ecolog. Chem. And Eng., 2015, 22, 401.

[16] Choma A., Kowalski D.: Rocznik Ochrona Srodowiska. 2016, 18 (2), 134.

[17] Kowalski D., Kwietniewski M., Musz A., Widomski M.: Ochrona Środowiska, 2008, 1, 27.

[18] Kowalski D., Kowalska B., Bławucki T. et al.: Water, 2019, 11, 480.

[19] Kowalski D., Miszta-Kruk K.: Eng. Failure Anal., 2013, $35,736$.

[20] Kozłowski E., Kowalska B., Kowalski D., Mazurkiewicz D.: Water Res Manag., 2019. https://doi.org/10.1007/ s11269-019-02419-0

[21] Kozłowski E., Mazurkiewicz D., Kowalska B., Kowalski D.: Application of a multidimensional scaling method to identify the factors influencing on reliability of deep wells [in:]: Intelligent Systems in Production Engineering and Maintenance 2019, 56-65.

[22] Rak. J.: Metody oceny niezawodności i bezpieczeństwa dostaw wody do odbiorców Politechniki Rzeszowskiej 2013.

[23] Kowalski D.: Nowe metody opisu struktur sieci wodociągowych do rozwiązywania problemów ich projektowania i eksploatacji. Monografie Komitetu Inżynierii Środowiska PAN, 2011, 88.

[24] Kowalska B., Kowalski D., Łagód G., Widomski M.: Modelling of hydraulics and pollutants transport in sewer systems : with exemplary calculations in SWMM. Politechnika Lubelska 2013.

[25] http://www.mpwik.pulawy.pl/aktualnosci-innowacyjnagospodarka.html

[26] http://www.mpwik-zywiec.pl/projekty-ue/oczyszczaniesciekow-w-zywcu-etap-ii-1.html

[27] Hirol M., Łagód G., Kowalski D., Procenko S. B.: Proektuvannâ sistem vodovìdvedennâ, očišennâ ta utilìzaciï stičnih vod $\mathrm{v}$ malih naselenih punktah ta sìl's’kìj mìscevostì. Nacìonal'nyj Universitet Vodnogo Gospodarstva Ta Prirodokorictuvannâ 2013.

[28] Bugała R., Borowczyk-Zalewska M., Kowalski D. et al.: Warunki techniczne wykonania sieci wodociągowokanalizacyjnych. Zeszyt Specjalny Izby Gospodarczej "Wodociągi Polskie" 2017. 